\title{
Clinicopathological and immunohistochemical features of the severe pulmonary form of leptospirosis
}

\author{
Aspectos clínico-patológicos e imuno-histoquímicos \\ da forma pulmonar grave da leptospirose
}

\begin{abstract}
João José Pereira da Silva1, Marcos Olivier Dalston', Jorge Eduardo Manhães de Carvalho', Sérgio Setúbal' ${ }^{1}$, Janice Mery Chiarino de Oliveira ${ }^{2}$ and Martha Maria Pereira ${ }^{2}$
\end{abstract}

\begin{abstract}
Four cases of severe pulmonary form of leptospirosis (SPFL) are described. In all four of these blood culture proven cases, there was severe pulmonary injury characterized by alveolar hemorrhage and acute respiratory failure. Three patients died in less than 48 hours after onset of the first respiratory signs. Leptospiral antigen detection in lung tissues was positive by immunoperoxidase in all three of these cases, suggesting that the microorganism exerts a local direct destructive action. Patients with SPFL should be carefully monitored, as the abrupt onset of severe alveolar hemorrhage can lead to respiratory insufficiency and death. The authors emphasize the importance of radiological findings and blood gas analysis for prompt clinical diagnosis, and suggest that corticosteroids, associated with antibiotics, early respiratory support, and platelet transfusions are useful as an attempt to prevent further development of SPFL.
\end{abstract}

Key-words: Leptospirosis. Weil's disease. Pulmonary hemorrhage.

Resumo São descritos quatro casos da forma pulmonar grave da leptospirose (FPGL). Nestes quatro casos confirmados por hemocultura, observou-se grave acometimento pulmonar, caracterizado por hemorragia alveolar e insuficiência respiratória aguda. Três pacientes evoluíram para o óbito em menos de 48 horas após a instalação do quadro respiratório. A detecção por imunoperoxidase de antígenos de leptospira no tecido pulmonar foi positiva nestes três pacientes, sugerindo ação lesiva direta deste microrganismo. Os autores destacam a importância do diagnóstico clínico precoce, baseado nos achados radiológicos e de gasometria arterial, e sugerem que os corticosteróides, associados à antibioterapia, à assistência ventilatória precoce e à transfusão de plaquetas, são úteis na tentativa de impedir a instalação de grave hemorragia alveolar seguida de insuficiência respiratória e morte.

Palavras-chaves: Leptospirose. Doença de Weil. Hemorragia pulmonar.

Leptospirosis is an acute infection caused by Leptospira interrogans. Most cases present clinically as mild and selflimited disease. Some patients may present a more severe course, characterized by jaundice, acute renal failure and hemorrhages. This clinical picture has been referred to as Weil's disease ${ }^{6}$. Besides this classical presentation, severe leptospirosis may present with prominent pulmonary symptoms ${ }^{20} 22$. Although described in other regions of the world, such as Asia ${ }^{519}$, the severe pulmonary form of leptospirosis (SPFL) was not recognized in Brazil, particularly in Rio de Janeiro State, until the eighties, when the first cases began to appear ${ }^{20} 21$.

SPFL manifests itself by pulmonary hemorrhage, which is usually massive and leads to respiratory insufficiency and death by asphyxiation ${ }^{413}$. It may antecede all other typical leptospirosis manifestations, such as jaundice and acute renal failure ${ }^{1}$. Once established, the respiratory picture has a rapid and severe course, with mortality rates as high as $30 \%$ to $60 \%{ }^{1117}$. Its pathogenesis has yet to be clarified, and several causal factors are suggested, such as the etiologic agent itself, the immune status of the host, and environmental conditions $^{14}$. From a clinical standpoint, the diagnosis should be made as soon as possible, in order to be followed by timely therapeutic measures intended to preclude the rapid evolution of severe lung hemorrhage, acute respiratory failure, and death.

Objectives. The clinicopathological and immunohistochemical features of four blood culture proven SPFL cases were studied with the objective of providing some contribution to the understanding of SPFL pathogenesis.

\footnotetext{
1. Disciplina de Doenças Infecciosas e Parasitária do Departamento de Medicina Clínica da Faculdade de Medicina da Universidade Federal Fluminense. Hospital Universitário Antônio Pedro, Niterói, RJ. 2. Serviço de Anatomia Patológica do Hospital Evandro Chagas da Fundação Oswaldo Cruz, Rio de Janeiro, RJ.

Address to: Dr. João José Pereira da Silva. Praia João Caetano 81/402, Ingá, 24210-405, Niterói, RJ, Brazil.

Telefax: 552127197262.

e-mail:dipuff@zipmail.com.br

Recebido para publicação em 19/6/2001.
} 


\section{CASE REPORTS}

Patient 1. A previously healthy 32-year-old afrobrazilian, was admitted to Antônio Pedro University Hospital (HUAP) on December 23, 1998, with a sevenday history of high fever, rigors, headache, and widespread myalgia. Five days before admission he noticed dark urine, jaundice and started to cough. There were no chest pain, hemoptysis, or dyspnea. On admission the patient was dehydrated and jaundiced, and had conjunctival suffusions. Temperature was $39.5^{\circ} \mathrm{C}$, blood pressure $80 / 40 \mathrm{mmHg}$, pulse rate $100 / \mathrm{min}$, and respiratory rate $30 / \mathrm{min}$. There was rale and diminished respiratory sounds in the right base. Chest $\mathrm{X}$ rays revealed a lower right interstitial infiltrate. Arterial blood gases (under room air) showed $\mathrm{pH} 7.49, \mathrm{pCO}_{2}$ $38.4 \mathrm{mmHg}, \mathrm{pO}_{2} 74.2 \mathrm{mmHg}, \mathrm{HCO}_{3} 29.3 \mathrm{~mm} / \mathrm{l}$, and oxygen saturation $89 \%$. Twenty-four hours after admission the patient worsened and became dyspneic. A further chest radiography showed diffuse interstitial micronodular bilateral infiltrates. New arterial blood gases showed $\mathrm{pH} 7.51, \mathrm{pCO}_{2} 32.5 \mathrm{mmHg}, \mathrm{pO}_{2}$ $63.6 \mathrm{mmHg}, \mathrm{HCO}_{3} 26.1 \mathrm{~mm} / \mathrm{l}$, and oxygen saturation $80 \%$. Oxygen was administered by facemask. Improvement was noticed in 48 hours. Serial chest radiographs showed progressive improvement. The patient was discharged from the hospital 10 days after admission. A microscopic agglutination test was positive up to $1 / 16,000$. There was no renal failure.

Patient 2. A previously healthy 23-year-old afrobrazilian, was admitted on January $1^{\text {st }}, 1999$ to HUAP with a seven-day history of fever, rigors, headache, and vomiting. Three days earlier he had noticed diarrhea, dry cough and become breathless. On admission he was jaundiced and looked severely ill. He had a temperature of $38^{\circ} \mathrm{C}$ and a respiratory rate of 60 per minute. Pulse rate was 120/min, and blood pressure 190/ $130 \mathrm{mmHg}$. Respiratory sounds were barely audible throughout both lung fields, and there was rale at the bases. There was calf pain on palpation. Chest X-rays revealed a diffuse nodular infiltrate, somewhat more intense peripherally. Arterial blood gases under room air were $\mathrm{pH} 7.42, \mathrm{pCO}_{2} 28.5, \mathrm{pO}_{2} 39.7 \mathrm{mmHg}$, and oxygen saturation $76.3 \%$. The patient was intubated and mechanically ventilated with $100 \%$ oxygen. Notwithstanding this, he developed progressively worsening respiratory failure, and sanguineous respiratory secretions. Twelve hours after admission the patient had a cardiac arrest and died. A microscopic agglutination test was negative.

Patient 3. A previously healthy 28 -year-old white housewife, presented with a seven-day history of fever, rigors and severe calf and thigh pain. She was admitted on November 19, 1998 to HUAP. Five days before admission she had begun to expectorate small amounts of blood and become progressively dyspneic. On admission she looked severely ill, despite being fully conscious. She was febrile $\left(38^{\circ} \mathrm{C}\right.$, axillary), dyspneic (58 per minute), and had cyanotic extremities. There was pallor but no jaundice. Blood pressure was 115/ $80 \mathrm{mmHg}$, and pulse rate was $124 / \mathrm{min}$. Respiratory sounds were audible, albeit diminished in the right base, and there was rale in both bases. The abdomen was supple, but there was diffuse tenderness on deep palpation. The liver was not palpable. There was calf and thigh pain on palpation. Chest radiographs revealed extensive alveolar infiltrates in the lower thirds of both lungs. Chest computerized tomography showed diffuse (although predominantly peripheral) ground glass pattern. There were no abnormalities on electrocardiogram. Arterial blood gases (on room air) showed pH 7.46, $\mathrm{pCO}_{2} 31 \mathrm{mmHg}, \mathrm{pO}_{2} 53 \mathrm{mmHg}, \mathrm{HCO}_{3}$ $22 \mathrm{~mm} / \mathrm{l}$, and oxygen saturation $89 \%$. Despite treatment, the patient developed worsening dyspnea, requiring intubation and positive pressure ventilation. No hemoptysis was noted. A new measurement of arterial blood gases showed $\mathrm{pH} 7.09, \mathrm{pCO}_{2} 86.7 \mathrm{mmHg}, \mathrm{pO}_{2}$ $40 \mathrm{mmHg}$, and oxygen saturation $54.2 \%$. Two days after admission the patient had a cardiac arrest and died despite attempts at reanimation. A microscopic agglutination test was negative

Patient 4. A 40-year-old white housewife, was admitted on March 3, 1998 due to dyspnea and hematemesis. Fever, rigors, headache and widespread myalgia had been noted seven days before and, two days before admission, she had begun to vomit small amounts of blood and become increasingly breathless. She was in respiratory distress on admission, with a respiratory rate of $40 / \mathrm{min}$. Temperature was $37.5^{\circ} \mathrm{C}$, pulse was $100 /$ min, and blood pressure was $100 / 80 \mathrm{mmHg}$. There was jaundice and conjunctival suffusion. Respiratory sounds were bilaterally diminished on both bases, and there was rale on the right one. The liver was not palpable. The patient developed rapid and progressively worsening dyspnea, and seizures. She was intubated, and mechanically hyperventilated with $100 \%$ oxygen. Arterial blood gases showed $\mathrm{pH} 7.34, \mathrm{pCO}_{2} 12.0 \mathrm{mmHg}, \mathrm{pO}_{2}$ $168.6 \mathrm{mmHg}, \mathrm{HCO}_{3} 6 \mathrm{~mm} / \mathrm{l}$, and oxygen saturation $99.2 \%$. One day after admission the patient had a cardiac arrest, which did not respond to reanimation measures. A microscopic agglutination test was negative.

Overview. All patients lived and worked in São Gonçalo, a vast and poverty stricken urban settlement near Niterói, Rio de Janeiro State, Brazil. Both male patients were construction workers, a kind of job which seems in our experience to be particularly linked to leptospirosis. All had a history of previous immersion in dirty water during the frequent urban floods that scourge São Gonçalo. Patient 1 also described the presence of rats in his work-place, and patient 3 reported many rodents in the surroundings of her home.

The initial diagnostic impression was leptospirosis in all four patients, and treatment was started with intravenous benzyl-penicillin (2 million units every 4 
hours), hydrocortisone ( $4 \mathrm{mg} / \mathrm{kg}$ every six hours) and platelet transfusions. Patient 3 also required blood transfusion (three units of packed red cells). The laboratory follow-up in the first 24 hours included platelet counts, prothrombin activity and partial thromboplastin time measurements, serial blood gas analysis and chest $x$-rays. Some features of the laboratory work-up are shown in Table 1.

Extensive areas of pleuropulmonary hemorrhage were found at necropsy in all three cases. On microscopy, there were widespread hemorrhagic infiltrates involving alveoli and septa. The absence of fibrinous material within lung capillaries indicated against the occurrence of disseminated vascular coagulation. All four cases had ante-mortem positive blood cultures for Leptospira interrogans serovar copenhageni. For better accuracy, the serovars were characterized through monoclonal antibodies. This prompted the post-mortem detection of leptospiral antigen in lung tissues. For this latter procedure, antibodies against Leptospira interrogans serovar copenhageni were employed. Finely granular positive reactions corresponding to leptospira engulfed by macrophages were found in septa and alveoli (Figure 1). Leptospiras are rarely detected in lung tissue by conventional methods and immunoperoxidase was extremely useful not only in supporting the diagnoses but also in demonstrating leptospiral antigen in the affected areas ${ }^{9}$, thus underscoring its importance in the pathogenesis ${ }^{23}$.

Table 1 - Blood and serum exams.

\begin{tabular}{lcccc}
\hline & Patient 1 & Patient 2 & Patient 3 & Patient 4 \\
\hline White blood cells $(\mu \mathrm{l})$ & 15,500 & 26,300 & 14,500 & 13,770 \\
Metamyelocytes $(\%)$ & 2 & - & - & - \\
Band forms $(\%)$ & 22 & 22 & 10 & 7 \\
Segmented neutrophils $(\%)$ & 61 & 64 & 58 & 61 \\
Hemoglobin $(\mathrm{g} / \mathrm{dl})$ & 10.9 & 8.3 & 7.9 & 6.9 \\
Platelet count $(\mu \mathrm{l})$ & 51,000 & 39,000 & 95,000 & 5,000 \\
Blood creatinine $(\mathrm{mg} / \mathrm{dl})$ & 4.9 & 5.4 & 1.1 & 4.4 \\
Bilirubin, total $(\mathrm{mg} / \mathrm{dl})$ & 7.9 & - & - & 19.2 \\
Bilirubin, direct $(\mathrm{mg} / \mathrm{dl})$ & 6.0 & - & - & 15.4 \\
AST (u/dl) & 143 & 100 & - & \\
ALT (u/dl) & 143 & & - & 72 \\
Prothrombin index $(\%)$ & 100 & 36 & 80 & 80 \\
APTT (patient/control) & $36 / 36$ & $36 / 36$ & $36 / 36$ & $38 / 38$ \\
\hline AST - Alanine aminotransfase
\end{tabular}

AST - Alanine aminotransferase; ALT - aspartate aminotransferase;

APTT - activated partial thromboplastin time.

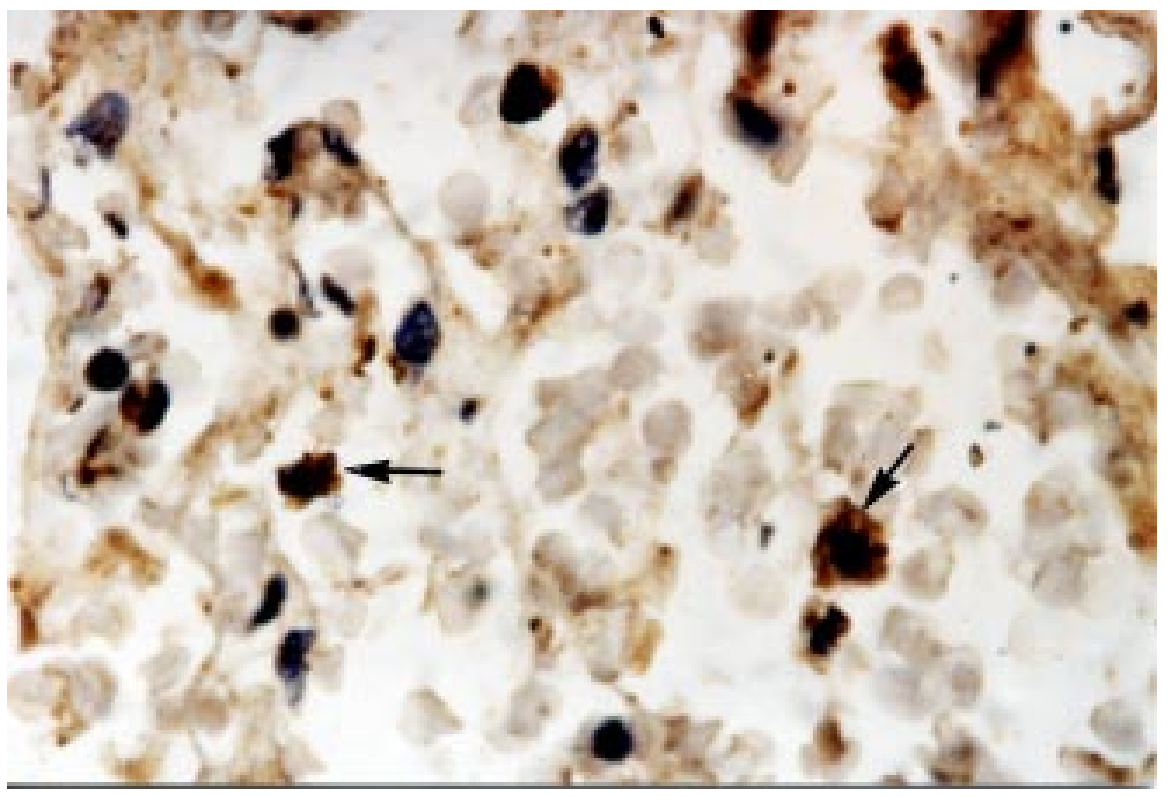

Figura 1 - Leptospiral antigen (arrow) in mononuclear cell of interalveolar septum, (avidinbiotin stained, 400x). 


\section{DISCUSSION}

SPFL is the most severe clinical presentation of leptospirosis. Respiratory symptoms usually appear between the fourth and sixth day of disease and may lead to death in less than 72 hours. The most remarkable aspect of this picture is profuse lung hemorrhage, which is predominantly due to capillary involvement and thrombocytopenia ${ }^{1223}$. Consumption coagulopathy is described by some authors ${ }^{4121623}$, but considered by others ${ }^{17}$ to be infrequent. There is some evidence that leptospira may activate or harm capillary endothelium cells ${ }^{1023}$, leading to profuse leaking of plasma into the interstitium, with consequent hypovolemia, and generalized hemorrhages. Toxic substances produced by the pathogen, such as endotoxins, or by cytokineproducing activated host cells, for instance tumor necrosis factor (TNF), seems to be important in the pathogenesis 61016 . In leptospirosis as in dengue, Hantavirus infections and sepsis, there is an intense leak of fluid and proteins into the intravascular space. In leptospirosis, however, this is also accompanied by the extrusion of erythrocytes, resulting in a picture of widespread hemorrhagic infiltrates. In the lungs, the capillary endothelium lesion is manifested as pneumonitis with hemorrhagic infiltrates and edema in the alveoli and septa ${ }^{1520}$. Alveolar invasion by edema fluid and erythrocytes importantly alter the gas exchanges, ultimately leading to hypoxemia. The respiratory clinical picture is initially unimpressive, with nothing beyond mild dyspnea, sometimes associated to hemoptoic expectoration ${ }^{11}$. Arterial blood gases usually exhibit little changes initially, and the chest $x$ ray may be entirely normal or display bilateral interstitial infiltrates. The evolution, however, is rapidly progressive, and in a few hours there will be obvious dyspnea and respiratory distress, accompanied by frank hemoptysis. At this point, the patient will exhibit severe changes in arterial blood gases, and the chest x-ray will show striking deterioration with extensive bilateral interstitial infiltrate and areas of alveolar filling ${ }^{1722}$. These radiological findings may be similar to those seen in viral pneumonia, bronchopneumonia, miliary tuberculosis, pulmonary hemorrhages and in adult respiratory distress syndrome $(A R D S)^{3}$. Thrombocytopenia is also very frequent ${ }^{17}$. Thrombocytopenia was observed at the beginning of the respiratory symptoms in three of our patients. The deaths were consequent to severe respiratory failure due to pulmonary hemorrhage.

The presence of leptospiral antigen correlated with tissue lesions in the lungs, suggesting a direct action of the microorganism (or of its byproducts) in the genesis of the tissue lesions observed in SPFL ${ }^{17}$. Alves and colleagues ${ }^{2}$ and Nicodemo and colleagues ${ }^{17}$ considered this direct action the factor responsible for the attacking of parenchymatous and vascular endothelial cells.

Clinical suspicion of alveolar hemorrhage has been fundamental for initiating therapeutic measures, which included, in addition to hemodynamic and respiratory support, also corticosteroids and platelet transfusions ${ }^{24}$. Bronchoscopy with bronchoalveolar lavage may, however, be useful in confirming the existence of hemorrhage, which may initially be occulted ${ }^{4}$. Medical care should consist of cardio-respiratory and gasometric monitoring, and follow-up of blood clotting parameters, especially platelet counting. Attending physicians should be aware that early and strong measures against respiratory failure are mandatory, even in the beginning, when it almost always seems unimportant. Timely indicated mechanical ventilation with PEEP (as well as corticosteroids) may be a lifesaving measure, considering the speed of the appearance and the copiousness of the hemorrhage, which frequently leads the patient to asphyxia and death ${ }^{18}$. Another effective measure is early platelet transfusion, indicated in all patients with less than 50 thousand platelets per cubic millimeter, or in those who present, in a short period of time, expressive reductions in the platelet count values.

\section{REFERENCES}

1. Allen P, Raftery S, Pheland D. Massive pulmonary haemorrhage due leptospirosis. Intensive Care Medicine 15:322-324, 1989.

2. Alves VAF, Siqueira SAC, Pestana CB. Patologia da leptospirose. Análise crítica dos aspectos morfológicos e imuno-histoquímicos relevantes para a compreensão da patogenia. Revista do Instituto Adolfo Lutz 49:75-80, 1989.

3. Carvalho JEM, Marchiori ES, Guedes e Silva JB, Souza-Netto BA. Tavares W, De Paula AV. Comprometimento pulmonar na leptospirose. Revista da Sociedade Brasileira de Medicina Tropical 25:1 21-30, 1992.

4. Carvalho JEM, Oliveira JMC, Nicol AF, Dalston MO, Vilar EAG, Rodrigues CC, Santos PRN, Pereira, MM, Pereira da Silva JJ. Identificação da leptospira em tecido pulmonar por broncofibroscopia e biópsia brônquica. Pulmão RJ 8:377-381, 1999.

5. Chiu YC, Lin HH. Report on observation of roentgenologic pulmonary changes in 48 cases of leptospirosis. Chinese Journal Radiology 7:374-375, 1959.
6. Dobrina A, Nardone E, Vecile M, Cinco M, Patriarca P. Leptospira icterohaemorrhagiae and leptospire peptidoglycans induce endothelial cell adhesiveness for polymorphonuclear leukocytes. Infection and Immunity 63:2995-2999, 1995.

7. Du Couëdic L, Coutrin JP, Poubeau P, Tanguy B, Di Francia M, Aruin-Berod C. Hemorragic intra-alvéolaires patentes et occultes au cours des leptospiroses. Revue des Maladies Respiratoire 15:61-67, 1998.

8. Edwards GA, Domm BM. Leptospirosis. Medical Times 94:906913, 1966.

9. Ellis TM, Robertson GM, Gustas L, Kirby M. Detection of leptospires in tissue using an immunoperoxidase staining procedure. Australian Veterinary Journal 60: 364-367, 1983.

10. Estavoyer JM, Racadot E, Couetdic G, Leroy J, Grosperrin L. Tumor necrosis factor in patients with leptospirosis. Review of Infectious Diseases 13:1245-1246, 1991. 
11. Friedland JS, Warrell DA, The Jarisch-Herxheimer reaction in leptospirosis: Possible pathogenesis and review. Review of Infectious Diseases 13:207-210, 1991.

12. Higgins R, Cousineau G. The pathogenesis of leptospirosis. Canadian Veterinary Journal 22: 277-278, 1981.

13. Im J, Yeon KM, Han MC, Webb, WR, Lee JS, Han YC, Chang WH, Chi JG. Leptospirosis of the lung: radiographic findings in 58 patients. American Journal of Radiology 152:955-959, 1989.

14. Isogai E, Isogai H, Fujii N, Oguma K. Macrophage activation by leptospiral lipopolysaccharide. Revue des Maladies Respiratoire 273:200-208, 1990.

15. Labalme MJ, Chaabane-Masmoudi S, Mathieu M, Perol M, Nesme $P$, Guérin JC. Hémorragie intra-alvéolaire fébrile isolée révélant une leptospirose. Revue des Maladies Respiratoire 13:310-312, 1996.

16. Macedo V, Figueiredo JFM, Carvalho E, Barbosa E. Coagulação intravascular disseminada na leptospirose. Revista de Patologia Tropical 3:363-366, 1973

17. Nicodemo AC, Duarte MIS, Alves AF, Takamura CFH, Santos RTM, Nicodemo EL. Lung lesions in human leptospirosis: microscopic, immunohistochemical, and ultrastructural features related to thrombocytopenia. American Journal of Tropical Medicine and Hygiene 56:181-187, 1997.
18. O'neil KM, Rickman LS, Lazarus AA. Pulmonary manifestations of leptospirosis. Review of Infections Diseases 13:705-709, 1991.

19. Poh SC, Soh CS. Lung manifestations in leptospirosis. Thorax 25:751-755, 1970.

20. Rios-Gonçalves AJ, Rozenbaum R, Vieira ARM, Manhães de Carvalho JE, Guedes e Silva JB. Mudanças dos padrões clínicos e anatomopatológicos da leptospirose na cidade do Rio de Janeiro e Grande Rio. Jornal Brasileiro de Medicina 64:127-137, 1993.

21. Rios-Gonçalves AJ, Rozenbaum R, Borges VM, Vieira ARM. Leptospirose uma patologia em metamorfose. Revisão de conceitos. Arquivos Brasileiro de Medicina 66:3-6, 1992.

22. Silva JJP, Manhães de Carvalho JE, Xavier MM, Lutz TM, Setúbal $\mathrm{S}$, Dalston MO. Forma pulmonar grave da leptospirose (FPGL): uma nova apresentação clínica da doença no Estado do Rio de Janeiro, Brasil. Arquivos Brasileiro de Medicina 72:169-171, 1998.

23. Silva JJP, Souza-Netto BA, Lilembaum W, Alvim MEAM, Oliveira AV, The hemorrhagic syndrome of leptospirosis: an experimental study in guinea pigs. Revista da Sociedade Brasileira de Medicina Tropical 28:169-177, 1995.

24. Yersin $C$, Boret $P$, Mérien $F$, Clément $J$, Laille $M$, van Raust $M$, Perolet P. Pulmonary hemorrhage as an predominant cause of death in leptospirosis in Seychelles. Transactions of Royal Society of Tropical Medicine and Hygiene 94:71-76, 2000. 